\title{
How has GIRFEC Affected Multi-Agency Working in the Assessment Process?
}

\section{Hanin Rasheed}

ISSN: 2311-8636 (Print)

ISSN: 2312-2021 (Online)

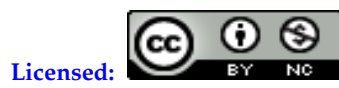

Source of Support: Nil

No Conflict of Interest: Declared

Email for correspondence: researchwriting0@gmail.com

20 Stone Grove Gardens, London, Nottingham, UK

\begin{abstract}
GIRFEC approach was carried out in this research in order to test the effectiveness, durability and strength along with its shortcomings, which works for the betterment of children and youth of Scotland (Government of Scotland, 2015). The study carried out by the author is to understand the interpretation and calculations of the multiple agencies that work for this cause. The existences of these agencies is not a new thing in Scottish environment and with the
\end{abstract} participation of parents and these agencies, the researcher found that for many years now, working of the agencies together in order to support team work had been encouraged. As the collaboration of the parents and multiple agencies has its perks and showed better results over the years, there were many researches that showed that in some agencies, they lacked team work and they were not compatible and because of that it resulted into deaths of many children across the UK (Hammond et al., 2010; Laming, 2003; Lord, 2009, Department for Education, 2010). Researcher in the current study focal point revolved around the idea of how the agencies carried out their investigations and if it had shown any better results for the parents and their children.

Keywords: GIRFEC, Multi-Agency Working, Team Development

\section{INTRODUCTION}

Professional development could simply be explained as the process of enhancing or improving the capabilities of an individual through access to training, and educational opportunities. There are a number of approaches which could lead towards professional development. I started my professional career working within the retail industry, where I worked for around two years, however, I was more interested to working within the travel industry, due to which I shifted to a travel agency located in Finland. The company was owned by one of my relatives, I worked there for some time and then I moved back home to England to continue my education, and learn about the professional skills, and knowledge which are essential to success within the travel and tourism industry.

Hence, the purpose of this paper is to conduct an in-depth analysis of the concept of professional development, with specific focus over the theories of Honey \& Mumford, and Belbin, as their work is quite essential when it comes to professional development, and would surely help be in understanding how I could grow as a professional within the travel and tourism industry. 


\section{HONEY \& MUMFORD}

When it comes to professional development, developing an understanding of the own learning styles, helps in ensuring that you as an individual are capable of retaining information in an appropriate manner, while at the same time it also ensures that you are capable of getting the most out of each development opportunity. Honey \& Mumford (1986) proposed 4 different learning styles, which could aid my professional development in the field of tourism (Honey, 2001). The four types are:

Activist: These are the people who learn by doing, they have an open-minded approach towards learning, and they like to get themselves involved completely in new experiences.

Reflector: These are the people who usually learn through observation, these type of learners avoid leaping into situations, rather they prefer to watch and learn (Van Zwanenberg, Wilkinson, and Anderson, 2000). They collect data, and then apply it in practice in order to ensure appropriate conclusion.

Theorist: They usually prefer to develop an understanding of the theory behind actions, and requires models, facts, and concepts for engaging in a learning process.

Pragmatist: These are the people who put their learning into practice in the real world, they prefer experimentation, and trying our new theories, and ideas to view if they work.

Hence, after conducting an in-depth analysis of the theory I would like to state that the learning style which I would prefer to follow in order to ensure effective professional development in tourism sector would be reflector, as through following this learning approach I would be able to first learning the essential aspects related to the industry, and how work is performed in different departments. Afterwards, I would implement my learning into practice to ensure positive outcomes, and successful professional growth.

\section{Belbin Theory of Team DeVelopment}

Belbin stated that, "A tendency to behave, contribute and interrelate with others in a particular way" (Aritzeta, Swailes, and Senior, 2007). Hence, Belbin states that every individual possess the tendency of behaving in a specific way, while working alongside others, however, it does not at all mean that this is the manner in which they will always behave (Prichard, and Stanton, 1999). Thus, Belbin concluded that there exists common cluster of these behaviours, which are stable enough to identify separately. They defined a total of 9 team roles, which includes:

- Coordinator: Who balances people and tasks

- Sharper: Who drives the whole project to completion

- Team Worker: Works well with others

- $\quad$ Resource Investigator: Investigates and find solutions to problems

- Implementer: Implements the required solution

- Complete Finisher: Works till the completion of project

- Monitor-Evaluator: Monitors and evaluates the situation

- Plant-Innovator: One who comes up with innovative solutions

- Specialist: One who gives depth to expertise

Among, all these roles in my opinion the role which is more feasible for me to succeed in the tourism industry is the team worker, as in tourism industry most of the organisations have different teams working in different departments towards the achievement of team 
targets. Therefore, the role which I would like to adapt is of team worker, as would help me in developing myself as a successful professional working within the tourism industry.

\section{REFERENCES}

Aritzeta, A., Swailes, S. and Senior, B., 2007. Belbin's team role model: Development, validity and applications for team building. Journal of Management Studies, 44(1), pp.96-118.

Department for Eduction. (2010) Haringey Local Safeguarding Children Board Serious Case Review 'Child $A^{\prime}$, Department for Education.

Hammond, E., McKinnon, E. and Nolan, D., 2010. Human Immunodeficiency Virus TreatmentInduced Adipose Tissue Pathology and Lipoatrophy: Prevalence and Metabolic Consequences. Clinical Infectious Diseases, 51(5), pp.591-599.

Honey, P. \& Mumford, A. (1986) The Manual of Learning Styles. Maidenhead, Peter Honey.

Honey, P., 2001. Honey and Mumford learning styles questionnaire. Peter Honey Learning. Retrieved April, 25, p.2007.

Laming, L. (2003) Inquiry into the death of Victoria Climbié, London, Stationery Office.

Lord, L. (2009) The Protection of Children in England: A progress report, London, The Stationery Office.

Prichard, J.S. and Stanton, N.A., 1999. Testing Belbin's team role theory of effective groups. Journal of Management Development, 18(8), pp.652-665.

Scottish Government. (2015) Children's Hearings [Online] Available at: http://www.gov.scot/Topics/People/Young-People/protecting/childrens-hearings. (Accessed 07/06/2015).

Scottish Government. (2015)Children and Young People (Scotland) Act 2014: The Scottish Government response to the consultation on the draft statutory guidance parts 4, 5 \& 18 (Section 96), Scottish Government, Edinburgh.

Van Zwanenberg, N., Wilkinson, L.J. and Anderson, A., 2000. Felder and Silverman's Index of Learning Styles and Honey and Mumford's Learning Styles Questionnaire: how do they compare and do they predict academic performance?. Educational Psychology, 20(3), pp.365-380. 
Publish Online and Print Version Both

Online ISSN: 2312-2021

Google Scholar: https://goo.gl/eozEWi 